\title{
98 | book review
}

\section{transnational feminism in film and media}

Katarzyna Marciniak, Aniko Imre and Aine 0'Healy (editors), Palgrave Macmillan, New York and Basingstoke, 2007, 248pp., ISBN: 978-1-4039-8370-1, £45.00

In this welcome addition to feminist film and media studies, the editors aim to 'forge a conceptual bridge between transnational feminism and transnational media' (p. 11). What new questions are made possible when these two fields are brought into conversation with each other? For the contributors to this volume, those questions centre around three interrelated concerns: the complexities of gendered movement in transnational contexts; the centrality of gender/nation intersections in the politics of location; and the power dynamics at work in representing the gendered/racialized other.

Although travel, movement and border crossing are an underlying preoccupation of all the essays, they are most directly engaged in Ginette Verstraete's discussion of feminist documentary filmmaker Ursula Biemann, and in Biemann's own fascinating contribution to the volume, 'Videographies of Navigating Geobodies'. Biemann's work aims to develop a visual language that can speak of the 'hypermobile, capitalized, gendered bodies that constitute transnational spaces' (p. 131). In Remote Sensing (2001), her topography of the global sex trade, she uses multiperspectival montages that combine individual women's accounts with digital images from the new technologies that both track and contextualize human movements. As Biemann explains, 'What became increasingly clear to me is that the notion of space is changing, not only due to the constant motion of people and things, but also thanks to the images we are able to generate technologically about geographic space' (p. 132).

Working through the gendered and sexualised complexities of location, and the tensions of local/national positioning in transnational contexts is a major preoccupation of many of the contributors. Asunam Suner's chapter on women's filmmaking in Iran and Turkey problematizes the now familiar distinction between 'accented' transnational cinema and what is seen as the boundedness of national cinemas. She argues that many of the characteristics of the 'accented' cinema of exile and diaspora can also be found in the work of women filmmakers who are very firmly located within their national cinemas, and who develop critiques of national belonging from within the space of the nation, through subversive constructions of female subjectivity. Patricia Pisters' article on transnational Moroccan 
women filmmakers also engages this question by examining how they work to gender the terms of national belonging, 'not in order to extinguish the nation, but precisely to open it up to the future, creating new possibilities of a less constrained life' (p. 81). Priya Jaikumar takes up similar themes in her reading of Pakistani woman director Sabiha Sumar's Khamosh Pani (Silent Waters, 2002). Here, women's problematic positioning in relation to national and religious identities, as well as to global power structures is the focus. The film's strength is in the central character's refusal to act within the impossible terms offered her between 'religion on national patriarchal terms and secularism on internationalist patriarchal terms' (p. 218). In a very different context and genre, Aniko Imre looks at the work of the Budapest Lesbian Film Collective. In their short film Puszta Cowboy (2004), 'the first Hungarian Lesbian-Transgender-Paprika Western', they work through the ambivalent relationship with nationalism that 'both prevents and enables lesbian identities at the same time' (p. 161). Marguerite Waller looks at Hungarian feminist filmmaker lbolya Fekete's exploration of transnational masculinity in her film Chico (2001).

Two other chapters also consider post-socialist politics of location and travel. Alice Mihaela Bardan's excellent examination of three European postsocialist journey films, Last Resort, Lilya 4-Ever and Code Unknown, identifies important resources for complicating our understanding of the transnational journeys undertaken by women in these films, and recasting our understanding of the nature of home and belonging. Lan Duong looks at the emerging commercial cinema in Vietnam that claims a transnational contemporaneity, arguing that it is in the spaces marked by globalization that renegotiations of what it means to be heterosexualised subjects take place (p. 176).

The volume's third theme is the power dynamics at work in representations of difference. Here, Bruce Bennett and Imogen Tyler provide an insightful reading of Michael Winterbottom's In this World and The Road to Guantanamo, asking whether the way in which refugees, immigrants and detainees are made visible and knowable invites a kind of 'border tourism' from its audience, in particular producing the refugee as 'a helpless, infantilized and feminized male figure' ( $p .27$ ) and positioning its presumed liberal European audience as benevolent saviour. Katarzyna Marciniak's essay 'Palatable Foreignness' reads recent US films My Big Fat Greek Wedding, and Spanglish, to critique a mode of representation 'that, in a benevolent gesture, may accept foreignness as long as the dominance of ... whiteness is not upset and as long as foreignness is treated like a "colourful bonus"' (p. 194). Aine 0 'Healy looks at the representation of migration in post-Cold War era Italian films, in which the recurring presence of the foreign prostitute is both 
eroticized and rendered abject in ways that recenter the agency of her Italian male rescuer.

For the impressive range of theoretical resources it draws on and, especially, the imaginative variety of new film texts it introduces and analyses, this volume is a very welcome contribution to the field of feminist film studies.

doi: $10.1057 / f r .2011 .18$

Irene Gedalof 